\title{
Development of Mechanical, Corrosion Resistance, and Antibacterial Properties of Steels
}

\author{
Marjetka Conradi
}

Citation: Conradi, M. Development of Mechanical, Corrosion Resistance, and Antibacterial Properties of Steels. Materials 2021, 14, 7698. https:// doi.org/10.3390/ma14247698

Received: 28 September 2021 Accepted: 4 December 2021 Published: 13 December 2021

Publisher's Note: MDPI stays neutral with regard to jurisdictional claims in published maps and institutional affiliations.

Copyright: (C) 2021 by the author. Licensee MDPI, Basel, Switzerland. This article is an open access article distributed under the terms and conditions of the Creative Commons Attribution (CC BY) license (https:// creativecommons.org/licenses/by/ $4.0 /)$.
Institute of Metals and Technology Ljubljana, Lepi pot 11, 1000 Ljubljana, Slovenia; Marjetka.Conradi@imt.si

The total cost and environmental consequences of corrosion problems have become a major challenge to engineers [1]. Steel is known as an important engineering material, mostly it has high corrosion resistance combined with favorable mechanical properties [2,3]. For example, the high corrosion resistance of stainless steel is attributed to the presence of a passive film, which is stable, invisible, thin, durable and extremely adherent and self-repairing [4,5]. However, in many aggressive environments, such as a chloride-ion-rich environment or under physiological conditions, the surface is still observed to suffer from corrosion. For example, reinforced concrete structures require continuous monitoring and maintenance to prevent corrosion of the carbon steel reinforcement [6]. Therefore, in the past two decades, the modification of metallic surfaces by various coatings, organic or polymeric, has become part of an important procedure in enhancing particular surface properties, such as scratch resistance, oxidation, and corrosion [7].

Stainless steels are commonly used materials in biomedical applications also because of their good biocompatibility [8]. However, an increasing number of clinical procedures require the development of materials with superior performance and higher reliability [9]. The major issues in biomedical applications are related to understanding the relationship between the material's surface properties and the cellular responses, accompanied by the risk of microbial infections [10]. The interaction of nanoscale surface topographies with cells was proven to play a crucial role in the biocompatibility of implants. Various nanoscale surface modifications have been proposed in order to enhance the biocompatibility and antibacterial activity of medical implants $[7,11]$. Biocompatible polymers, such as hydrophilic polyurethanes, poly(ethylene glycol), and poly(ethylene oxide) brushes, are known to reduce bacterial adhesion by alternating the physicochemical properties of the coating [12-14]. Epoxy resins are also extensively used to protect stainless steels because of their good chemical resistance, mechanical properties, strong adhesion with the substrate and corrosion protection by providing an effective physical barrier between the metal and the biological environment $[15,16]$. Mechanical properties in combination with biocompatibility can be further improved by adding nanoparticles into the epoxy resin, i.e., biocompatible $\mathrm{TiO}_{2}$ nanoparticles $[7,17]$. An alternative approach in modifying surface properties in terms of biocompatibility is treatment with highly reactive plasma, which may alter stainless steel topography, chemistry, and wettability under appropriate treatment conditions [18].

To conclude, the published papers indicate the scientific and technological relevance of the topics covered by the Special Issue. Therefore, this Special Issue represents an important contribution to the broader audience, which will result in an increased number of article readings as well as citations.

Funding: This research received no external funding.

Institutional Review Board Statement: Not applicable.

Informed Consent Statement: Not applicable.

Data Availability Statement: Not applicable. 
Conflicts of Interest: The authors declare no conflict of interest.

\section{References}

1. Potgieter, J.H.; Olubambi, P.A.; Cornish, L.; Machio, C.N.; Sherif, E.S.M. Influence of nickel additions on the corrosion behaviour of low nitrogen $22 \%$ Cr series duplex stainless steels. Corros. Sci. 2008, 50, 2572-2579. [CrossRef]

2. Ibrahim, M.A.M.; el Rehim, S.S.A.; Hamza, M.M. Corrosion behavior of some austenitic stainless steels in chloride environments. Mater. Chem. Phys. 2009, 115, 80-85. [CrossRef]

3. Hryniewicz, T.; Rokicki, R.; Rokosz, K. Corrosion characteristics of medical-grade AISI Type 316L stainless steel surface after electropolishing in a magnetic field. Corrosion 2008, 64, 660-665. [CrossRef]

4. Perez, C.; Collazo, A.; Izquierdo, M.; Merino, P.; Novoa, X.R. Characterisation of the barrier properties of different paint systems-Part I. Experimental set-up and ideal Fickian diffusion. Prog. Org. Coat. 1999, 36, 102-108. [CrossRef]

5. Mujanović, E.; Zajec, B.; Kosec, T.; Legat, A.; Hönig, S.; Zehethofer, G.; Mori, G. Activation and Repassivation of Stainless Steels in Artificial Brines as a Function of pH. Materials 2019, 12, 3811. [CrossRef] [PubMed]

6. Gartner, N.; Kosec, T.; Legat, A. Monitoring the Corrosion of Steel in Concrete Exposed to a Marine Environment. Materials 2020, 13, 407. [CrossRef] [PubMed]

7. Conradi, M.; Kocijan, A.; Kosec, T.; Podgornik, B. Manipulation of $\mathrm{TiO}_{2}$ Nanoparticle/Polymer Coatings Wettability and Friction in Different Environments. Materials 2020, 13, 1702. [CrossRef] [PubMed]

8. Yu, J.C.; Ho, W.K.; Lin, J.; Yip, K.Y.; Wong, P.K. Photocatalytic activity, antibacterial effect, and photoinduced hydrophilicity of TiO2 films coated on a stainless steel substrate. Environ. Sci. Technol. 2003, 37, 2296-2301. [CrossRef] [PubMed]

9. Visai, L.; De Nardo, L.; Punta, C.; Melone, L.; Cigada, A.; Imbriani, M.; Arciola, C.R. Titanium oxide antibacterial surfaces in biomedical devices. Int. J. Artif. Organs. 2011, 34, 929-946. [CrossRef] [PubMed]

10. Webb, K.; Hlady, V.; Tresco, P.A. Relative importance of surface wettability and charged functional groups on NIH 3 T3 fibroblast attachment, spreading, and cytoskeletal organization. J. Biomed. Mater. Res. 1998, 41, 422-430. [CrossRef]

11. Lan, M.-Y.; Liu, C.-P.; Huang, H.-H.; Lee, S.-W. Both Enhanced Biocompatibility and Antibacterial Activity in Ag-Decorated TiO2 Nanotubes. PLoS ONE 2013, 8, e75364. [CrossRef] [PubMed]

12. Kaper, H.J.; Busscher, H.J.; Norde, W. Characterization of poly(ethylene oxide) brushes on glass surfaces and adhesion of Staphylococcus epidermidis. J. Biomater. Sci. Ed. 2003, 14, 313-324. [CrossRef] [PubMed]

13. Minhas, B.; Dino, S.; Zuo, Y.; Qian, H.; Zhao, X. Improvement of Corrosion Resistance of TiO2 Layers in Strong Acidic Solutions by Anodizing and Thermal Oxidation Treatment. Materials 2021, 14, 1188. [CrossRef] [PubMed]

14. Kabel, K.I.; Labena, A.; Keshawy, M.; Hozzein, W.N. Progressive Applications of Hyperbranched Polymer Based on Diarylamine: Antimicrobial, Anti-Biofilm and Anti-Aerobic Corrosion. Materials 2020, 13, 2076. [CrossRef] [PubMed]

15. Galliano, F.; Landolt, D. Evaluation of corrosion protection properties of additives for waterborne epoxy coatings on steel. Prog. Org. Coat. 2002, 44, 217-225. [CrossRef]

16. Liu, F.W.; Yin, M.X.; Xiong, B.Y.; Zheng, F.; Mao, W.F.; Chen, Z.; He, C.; Zhao, X.; Fang, P. Evolution of microstructure of epoxy coating during UV degradation progress studied by slow positron annihilation spectroscopy and electrochemical impedance spectroscopy. Electrochim. Acta 2014, 133, 283-293. [CrossRef]

17. Kocijan, A.; Conradi, M.; Hocevar, M. The Influence of Surface Wettability and Topography on the Bioactivity of TiO $2 / \mathrm{Epoxy}$ Coatings on AISI 316L Stainless Steel. Materials 2019, 12, 1877. [CrossRef] [PubMed]

18. Resnik, M.; Benčina, M.; Levičnik, E.; Rawat, N.; Iglič, A.; Junkar, I. Strategies for Improving Antimicrobial Properties of Stainless Steel. Materials 2020, 13, 2944. [CrossRef] [PubMed] 